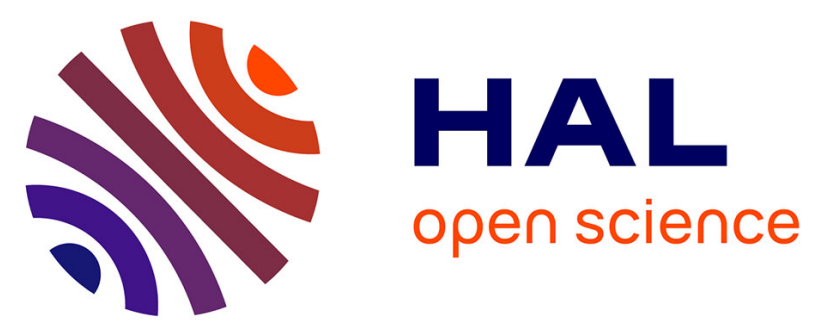

\title{
Groundwater recharge by Sahelian rivers-consequences for agricultural development: example from the lower Komadugu Yobe River (Eastern Niger, Lake Chad Basin)
}

P Genthon, Basile Hector, A Luxereau, M Descloitres, H Abdou, Jacques Hinderer, Michel Bakalowicz

\section{To cite this version:}

P Genthon, Basile Hector, A Luxereau, M Descloitres, H Abdou, et al.. Groundwater recharge by Sahelian rivers-consequences for agricultural development: example from the lower Komadugu Yobe River (Eastern Niger, Lake Chad Basin). Environmental Earth Sciences, 2015, 10.1007/s12665-0154119-y . ird-01122556

\author{
HAL Id: ird-01122556 \\ https://hal.ird.fr/ird-01122556
}

Submitted on 4 Mar 2015

HAL is a multi-disciplinary open access archive for the deposit and dissemination of scientific research documents, whether they are published or not. The documents may come from teaching and research institutions in France or abroad, or from public or private research centers.
L'archive ouverte pluridisciplinaire HAL, est destinée au dépôt et à la diffusion de documents scientifiques de niveau recherche, publiés ou non, émanant des établissements d'enseignement et de recherche français ou étrangers, des laboratoires publics ou privés.

\section{(ㅇ)(1) $\$$}

Distributed under a Creative Commons Attribution - NonCommerciall 4.0 International 


\title{
Groundwater Recharge by Sahelian Rivers : Consequences for Agricultural Development. Example from the Lower Komadugu Yobe River (Eastern Niger, Lake Chad Basin)
}

\author{
Genthon, P. ${ }^{1}$, Hector, B⿱2 , Luxereau, A. ${ }^{3}$, Descloitres, M. ${ }^{4}$, Abdou, H. $^{5}$, Hinderer, J. ${ }^{2}$, Bakalowicz, M. ${ }^{1}$
}

1 Hydrosciences Montpellier, Univ. Montpellier II 34095 Montpellier France, email: Michel.Bakalowicz@gmail.com, corresponding author at Pierre.Genthon@ird.fr

${ }^{2}$ IPGS-EOST, CNRS/UdS, 5 rue René Descartes 67084 Strasbourg, France, email: bhector@unistra.fr; jhinderer@unistra.fr

${ }^{3}$ UMR 7206, CNRS-MNHN-Paris VII, 75231 Paris cedex 05, France, email: Luxereau@mnhn.fr

${ }^{4}$ Laboratoire d'étude des Transferts en Hydrologie et Environnement UMR IRD,UJF, CNRS, INPG Université Grenoble 1, BP 53, 38041, Grenoble, France, email: Marc.Descloitres@ird.fr

${ }^{5}$ Direction de l'Hydraulique de Diffa, Diffa, Niger, email: Hachirouab@yahoo.fr

\begin{abstract}
In the Sahel region, temporary rivers and ponds constitute green spaces of welfare where sustainable development requires parsimonious management of water resources. The Komadugu Yobe (KY) valley in Eastern Niger is presented here as an example case of recent agricultural development based on irrigated pepper cropping. Piezometric maps indicate there that the river recharges the upper quaternary aquifer. A simplified numerical model allows to quantify the exchanges between the river on the aquifer, based mainly on exploration geophysics data and three piezometric records, covering between 1 and 3 years of our 4 years modeling period. Recharge at the valley axis is modeled with a linear river coefficient constant for each hydrological year. The main findings are that: (i) during dry years, the river is disconnected from the aquifer and separated from it by a layer of unsaturated medium, (ii) however, this effect can be reversed, such as during the 2010-2011 wet year or after the Sahelian drought event of the 1980s and 1990s, (iii) the infiltration rate from the river amounts to 30 to $40 \%$ of its total discharge and to at least four times the abstraction for pepper irrigation along its $150 \mathrm{~km}$ lower course at the Niger-Nigeria boundary, which implies that neither the aquifer recharge nor the river discharge are at risk due to the present agricultural development. Similar modeling near temporary river axes could provide some help in water resource management in the Sahel.
\end{abstract}

keywords: aquifer recharge, irrigated pepper farming, groundwater modeling, sustainable development, Lake Chad Basin, Komadugu Yobe 


\section{Introduction}

Water availability is a key factor for the sustainable development of Sahelian societies (Cheo et al. 2013; Babamaajii and Lee 2014). In several instances they can rely on groundwater mainly recharged in the past (Taylor et al. 2009; MacDonald et al. 2012) and from which the present renewal rate can be estimated (Scanlon et al. 2006), generally by geochemical methods (Edmunds 2009). In the northern Sahel, rivers, ponds and lakes constitute green spaces of relative welfare where the production activities rely on both surface water and groundwater (Tarhule and Woo 2002). Local water budgets are needed for estimating the water resource available for sustainable development (Carter and Alkali 1996). Numerical modeling of groundwater/surface water interaction may help to understand the effect of climate changes (Engelhart et al. 2013), to assess the consequences of various management scenarios (Feng et al. 2011) and to solve possible future conflicting uses.

Flowing at the eastern part of the boundary between Niger and Nigeria, the Komadugu Yobe (KY) is a sahelian temporary river which drains into Lake Chad (Fig. 1). This region was strongly impacted by the Great African Drought, which began during the 1970s and is considered as one of the most significant climatic events worldwide (Hulme 2001). Local people have achieved strong adaptation to the drought effects almost without external help (Mortimore and Adams 2001; Mortimore 2010). In the KY area they mostly substituted fishing and rainfed agriculture (pearl millet) with sweet pepper cropping irrigated with surface water, however with minor abstraction of groundwater (Luxereau et al. 2011). There are concerns on the sustainability of the development of this area given the limited water resource, the climate variability and the limited size of the pepper market.

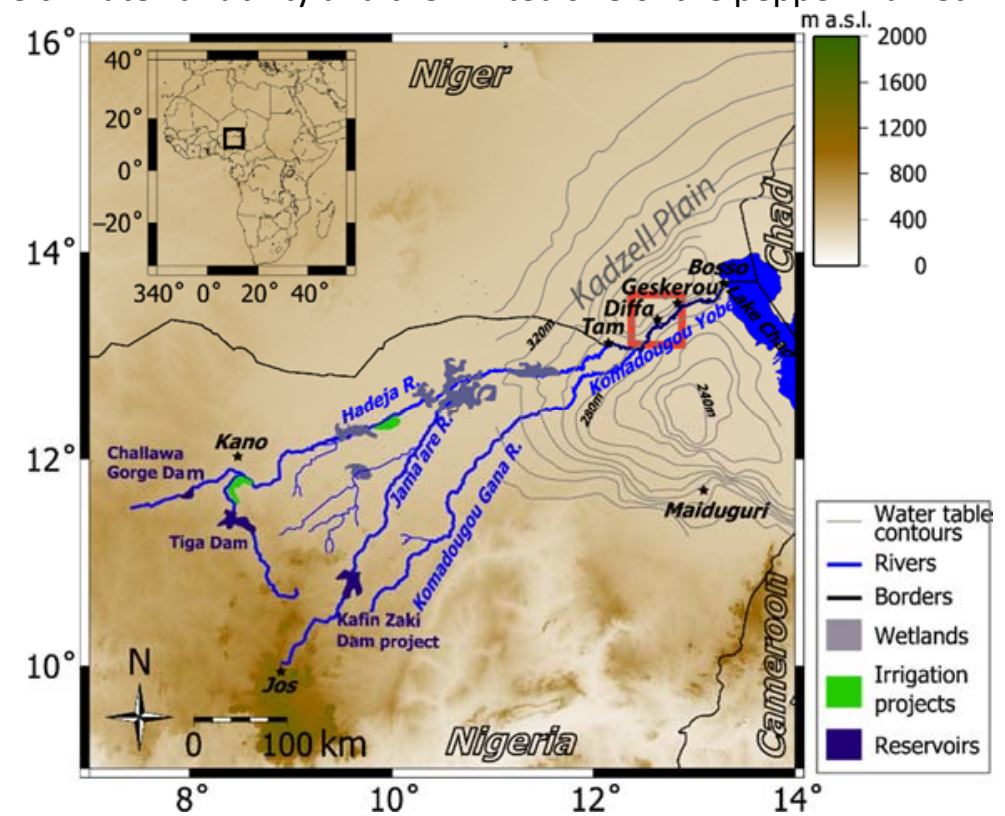

Fig. 1. The Komadugu Yobe (KY) river and its tributaries. The piezometric map, displayed as thin grey level curves evidences two depressions on both sides of the KY near Diffa and a piezometric ridge under the KY. The red square is centered around the study area near the city of Diffa.

Several models have been developed at the scale of the uppermost quaternary aquifer of the Lake Chad, as part of the PhD works of Leblanc (2002), Gaultier (2004), Zairi (2008) who took into account the variable climatic forcing and in Boronina and Ramillien (2008) who focused their work on evapotranspiration and on the infiltration budget. Candela et al. (2013) aimed to provide a user friendly model for the water planners of this area. One common conclusion of these models is that the Yobe River and the Lake Chad constitute presently the main recharge zones for the aquifer. However the poor coverage of their dataset, both in time and space and the resulting poor spatial resolution of the models produce large uncertainties in the water budget in the Yobe - Lake Chad area. Since 2005, thanks to a series of research projects additional data have been gathered in this area regarding (i) the changes of livelihood of local population since the African Drought and the development of 
irrigated agriculture (ANR/Biodivalloc ANR/Plantadiv and EC2CO/Repas projects), (ii) the structure and hydraulic properties of the quaternary aquifer, from exploration geophysics, direct sampling and piezometric data (IRD/Lake Chad, EC2CO/Repas, and ANR/Ghyraf programs).

The $K Y$ will therefore be considered as an example case for assessing the water budget of a combined river aquifer system in the Sahelian area. A conceptual model focused on the KY is proposed, and then a numerical model with a hundred meter spatial resolution is built near the city of Diffa. The first part of the present paper is devoted to the surface water changes in the Yobe River and the Lake Chad since the 1970s. The second one is devoted to the quaternary aquifer, its structure from exploration geophysics and fluctuations of water table, and finally to the outline of the resulting conceptual model. The third one discusses the results of numerical modeling of the response of the uppermost aquifer to the river flow regime and consequences for the water budget and the reaction of the river to drought events. Some hints on the sustainability of the development are given in conclusion. Detailed informations on the livelihood of local population and its changes triggered by the Drought are given in Online Resource 1, and additional information on the model, its optimization and validation can be found in Online Resource 2 .

\section{Surface water}

The Komadugu Yobe River (KY) originates in the wet highlands of the Jos Plateau in Nigeria. It flows through several wetlands before its entry in Niger and then is meandering over nearly $150 \mathrm{~km}$ in the Kadzell plain before reaching the Lake Chad (Fig. 1). The Kadzell plain itself is believed to have constituted the bed of the Megalake Chad that covered nearly $350000 \mathrm{~km}^{2}$ during the African Humid period nearly 6000 years ago (Leblanc et al. 2006). The KY is a non-steady river at the decadal to millennial timescale; significant changes in its course since 1950 are reported by Martinsson (2010) and a fossil valley of the $\mathrm{KY}$ can be seen $40 \mathrm{~km}$ northward of the present one. The present valley is 1 to $5 \mathrm{~km}$ wide and characterized by numerous abandoned meanders.

a

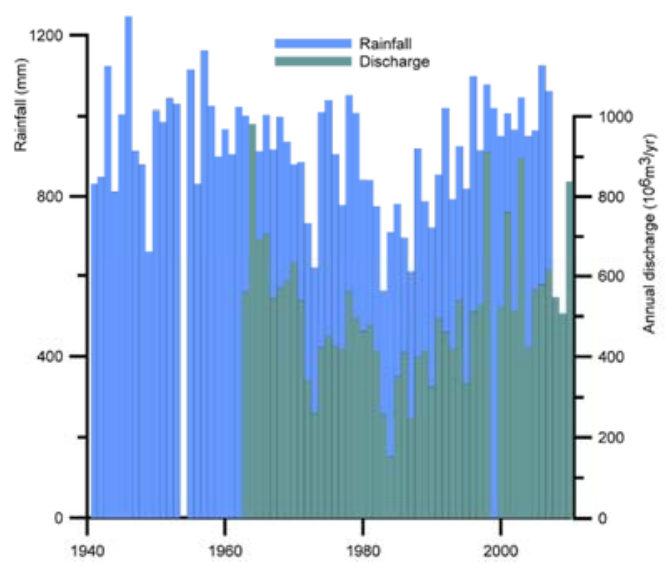

b

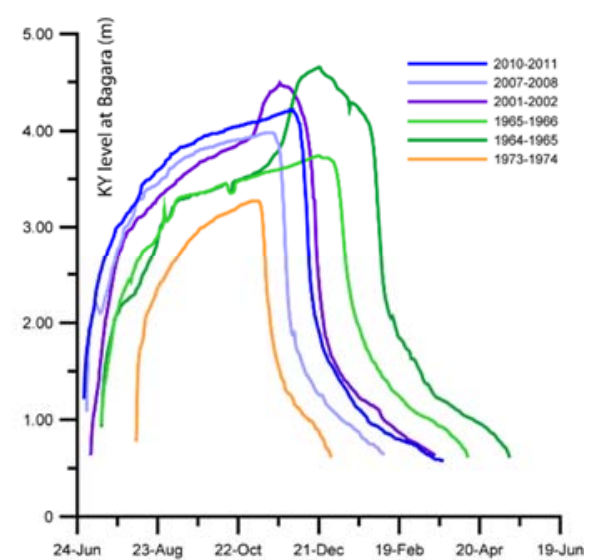

Fig. 2. Flow regime of the KY; a: comparison of the annual discharge of the KY and rainfall over its catchment area; $b$ : comparison of the water level of the KY at the Bagara station during the 1960s, for a dry year (73-74) and during recent years

The main source of data for the hydrology of the KY is the "Direction de I'Hydraulique" located in Diffa and the SIEREM database (Boyer et al. 2006). There are several gauging stations along the course of the KY in Niger (Tam, Bagara, Geskerou, Bosso) but Bagara, situated $5 \mathrm{~km}$ upstream Diffa is by far the most complete. The annual rainfall on its watershed was computed from both rain gauges and satellite data, with a weight shifting from rain gauges data before 2000 toward satellite data later on, using the method assessed for the whole Lake Chad hydrologic basin by Bastola and Delclaux (2011). Rainfall (Fig. 2a) exhibits the same rupture as the one noted in the West African Sahelian record by Le Barbé et al. (2002) and Mahé and Paturel (2009); the 1970s and especially the 
1980 s are marked by severe droughts. However, there is almost complete recovery of rainfall since the 2000s, as noted by Lebel and Ali (2009) for the whole Eastern Sahel.

The annual discharge of the KY appears to be mainly controlled by rainfall. It has been severely impacted by the drought of the 1970s and 1980s, but this impact was only transitory and discharges during recent years are comparable to those of the humid years of the 1960s (Fig. 2a). Some characteristic hydrographs of the KY at Bagara are displayed on Fig. $2 \mathrm{~b}$. The water level rises sharply at the onset of flow, generally between mid-June and the beginning of July. The wettest years present a second rise of water level at the end of the high flow period. All hydrographs are characterized by an abrupt drop of the level at the end of the flow period which indicates very little discharge from the aquifer during low flow. The influence of the major dams of Tiga and Challawa (Barbier 2003) built in 71-74 and in 90-92 on the upper tributaries of the KY is hardly detected in the hydrographs. However some large isolated peaks of discharge such as in 1998, 2001 and 2003 might be attributed to the management of these dams, since the discharge seems disproportionate with respect to the rainfall anomaly.

The Lake Chad is characterized by its large sensitivity to climate: Its northern pool, the only one to which people from Niger have access, was dried repetitively during the African Drought. Since the 1990s, the drought has alleviated and water has returned in the northern pool, but without reaching the level of the 1960s. More details on the hydrology of the Lake Chad can be found in Olivry et al. (1996), while a discussion focused on the region of the mouth of the KY is given in Luxereau et al. (2011). Due to the lesser availability of water from the Lake Chad local people had to turn toward the $\mathrm{KY}$, which induces a larger dependency to the KY hydrological regime.

\section{Groundwater with emphasis on the uppermost quaternary aquifer}

\subsection{The Quaternary aquifer near Diffa}

The KY valley overlies a series of superposed aquifers in the Lake Chad sedimentary basin (LeducPNUD, 1991). The uppermost quaternary aquifer is hydraulically isolated from lower aquifers by more than $100 \mathrm{~m}$ thick Pliocene clays (Greigert 1979; Schneider and Wolf 1992). Its hydraulic properties have been discussed by Greigert, (1979), Schneider and Wolf (1992), Leduc-PNUD (1991) and Eberschweiler (1993). It is nearly $80 \mathrm{~m}$ thick in the region of Diffa and consists mainly of silty sands alternating with sand or clayey layers of limited extension (Gumnior and Preusser 2007). We have now a precise knowledge of the uppermost $10 \mathrm{~m}$ of this aquifer thanks to the nearly 50 auger holes drilled and analyzed by Le Coz (Le Coz 2010; Le Coz et al 2011). They consist of silty sand with clayey lenses of a mean $200 \mathrm{~m}$ lateral extension and a $2 \mathrm{~m}$ mean thickness. It results that the semipermeable layers are not connected between each other and that there is continuity in the quaternary aquifer, which can therefore be modeled as a single aquifer with averaged transport properties. These data allow better understanding of the connection between the river and the shallow aquifer.

As an example, the four logging profiles near the Bagara school well (see location on Fig. 3) are displayed on Fig. 4a. A coarse sandy layer is generally present at the base of boreholes drilled across the whole aquifer for drinking water supply and it is suspected to produce a significant part of the yield of the borehole. The pumping tests carried out in these boreholes indicate transmissivity values ranging from $10^{-3} \mathrm{~m}^{2} \mathrm{~s}^{-1}$ to $2.810^{-2} \mathrm{~m}^{2} \mathrm{~s}^{-1}$. On the other hand hydraulic conductivity estimates at the scale of the whole aquifer provided by groundwater numerical models range from $10^{-6}$ to $10^{-5} \mathrm{~m} / \mathrm{s}$ with the highest conductivity near the river (Leblanc 2002; Gaultier 2004; Zairi 2008). 


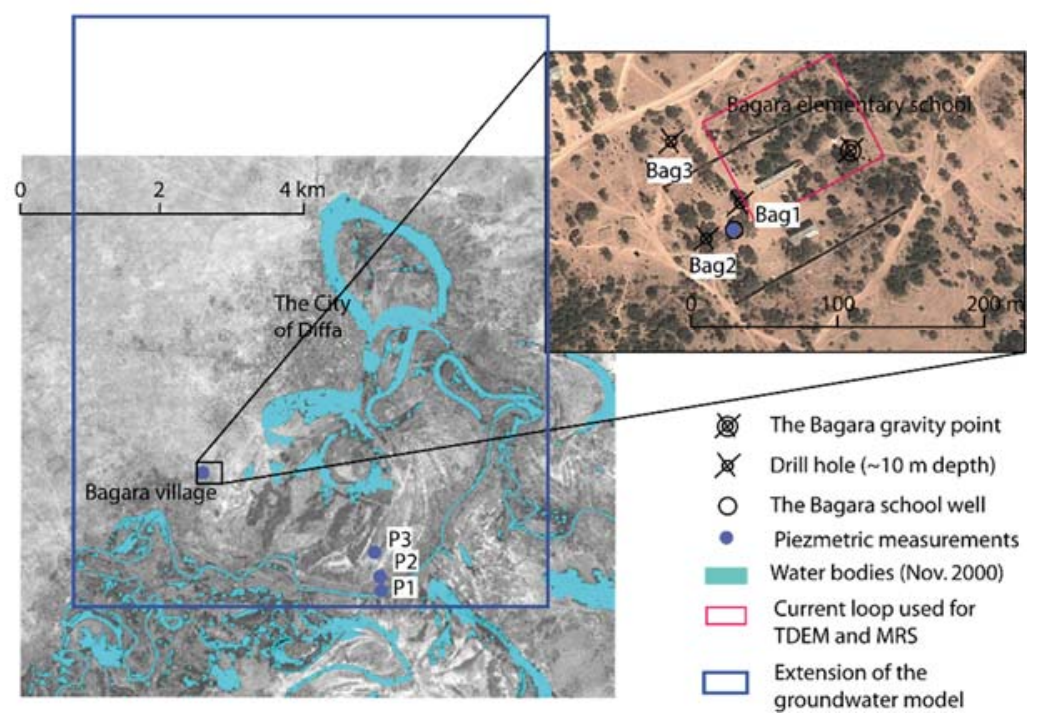

Fig. 3. The KY valley near Diffa with the location of the piezometers, well and geophysical measurement points used in this study. The blue heavy line correspond to the modeled area

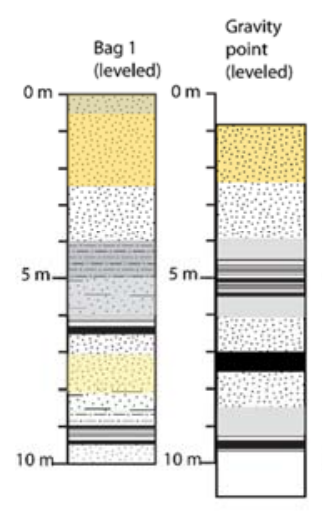

b

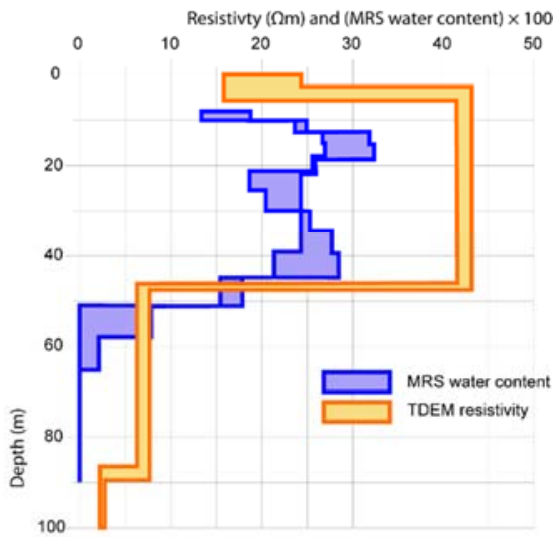

Fig. 4. a: sedimentary logs near the Bagara well (silty sands are in yellow and white, while grey and black indicate an increasing amount of clay); b: MRS water content and resistivity deduced from TDEM sounding at the Bagara school. See location on Fig. 3. The water level is nearly $9 \mathrm{~m}$ below the surface at the gravity point.

An exploration geophysics survey including Magnetic Resonance Sounding (MRS) and Time Domain Electromagnetism (TDEM) was achieved in 2008 on a $12 \mathrm{~km}$ long profile across the KY valley with an additional single point near the Bagara elementary school (Fig. 3) situated $6 \mathrm{~km}$ East of the profile. Magnetic Resonance Sounding (MRS) provides an estimate of the free water content through the saturated part of the aquifer as well as an estimate of grain size distribution related to the permeability of the aquifer (Legchenko et al. 2002). MRS water content is considered as an estimate of the effective porosity of silty and sandy aquifers. Time Domain Electromagnetism (TDEM) produces electrical resistivity soundings (Fitterman and Steward 1986). Combining informations from MRS and TDEM allows differentiating between clayey and silt layers. Clayey layers have low free water content (despite they contain bound-water undetectable by MRS) and low electrical conductivity, while silt and sand layers are characterized by both detectable MRS water content and a higher electrical resistivity (Guérin et al. 2001; Descloitres et al. 2013).

The whole exploration geophysics survey is published in a separate paper (Descloitres et al. 2013). It shows that: (a) the thickness of the KY aquifer ranges from 30 to $60 \mathrm{~m}$ tending to decrease at the borders of the KY valley and the aquifer is limited at depth by high electric conductivity clayed layers; 
a second conductivity drop is observed at $70-80 \mathrm{~m}$, which is attributed to massive Pliocene clays, (b) the mean porosity of the aquifer is $20-25 \%$ in the valley decreasing to $15 \%$ outside (c) high porosity (up to $30 \%$ ) and high permeability layers are observed locally at the base of this aquifer; they could correspond to the coarse sand levels noted in several borehole technical reports, (d) however MRS permeability estimates cannot be reconciled with those deduced from pumping tests. The Bagara sounding (Fig. 4b) shows a sharp decrease of both the electrical resistivity and the MRS water content near $50 \mathrm{~m}$ depth, which correspond to the clayed layers at the base of the quaternary aquifer, a mean MRS water content of $25 \%$ in the aquifer and a second drop of the resistivity near 90 $\mathrm{m}$ corresponding to the massive Pliocene clays. It is therefore characteristic of the KY valley.

\subsection{Water level}

The region of Diffa lies in the Northern Sahel area and therefore suffers from a 9-month dry season during which people not living near the KY have to rely on groundwater. Water levels were therefore measured early and piezometric maps are available since the 1960s, mainly as BRGM (the French Geological Survey) unpublished reports, which are summarized in Greigert (1979). Further discussions on the properties of the quaternary aquifer and on piezometric maps can be found in UNESCO (1972), IWACO (1985), Leduc-PNUD (1991), Carter and Alkali (1996), Leduc et al. (1998), Boronina and Ramillien (2005), Candela et al. (2013) and in the unpublished theses of Leblanc (2002), Gaultier (2004), and Zairi (2008).

The map included in Fig. 1 is redrawn after Zairi (2008) and includes a large set of new data on the southern rim of the KY in Nigeria. On this map the KY valley appears as a piezometric ridge surrounded by two depressions. This indicates that the KY constitutes a present zone of recharge for the quaternary aquifer, and therefore that without recharge by the river, the water level will flatten below the KY valley and will tend toward the level of the two piezometric depressions. The groundwater resource appears therefore at risk if the infiltration from the KY would decrease significantly.

Continuous piezometric records are extremely scarce. The Direction de I'Hydraulique in Diffa monitors 14 wells located at less than $5 \mathrm{~km}$ from the $\mathrm{KY}$ on a monthly basis but with several missing data. The standard deviation of the measurements was considered as a proxy for the annual water level variability in the wells. Fig. 5a shows that it decreases rapidly away from the river. This standard deviation is nearly $0.9 \mathrm{~m}$ close to the river and is less than $0.3 \mathrm{~m}$ at distances larger than $2 \mathrm{~km}$. However, due to the lack of continuity in the data record, these data cannot be used for quantitative modeling. Moreover, a 4 year long dataset including near monthly measurements and dating back from 1994 was found for the Assaga well in Gaultier's thesis (Gaultier 2004). The Assaga well is located $15 \mathrm{~km}$ downstream Bagara and $170 \mathrm{~m}$ away from the river axis.

The Bagara elementary school well, nearly $800 \mathrm{~m}$ away from the river (Fig. 3) constitutes the most continuous record with some data back from 1995 (Fig. 5c). Measurements are interrupted in 1997 and resume after 2005 with an offset of more than one meter. This could result from a change in reference level, since the well is cased with concrete rings constituting a nearly $1 \mathrm{~m}$ high edge. Since the 2000s the school benefits from tap water and the well is no more used. Our sensors were stolen in 2008 but the near periodicity of the water level allowed us to interpolate an approximate curve (dotted line) during the missing months.

A piezometric profile was set up at the end of 2008 perpendicularly to the river. It consists of 3 auger holes (P1-3) drilled at $50 \mathrm{~m}, 290$ and $600 \mathrm{~m}$ from the river axis (Fig. 3) which were monitored weekly over a 1yr duration. P2 and P3 are located in a non cultivated areas and P1 is inside an irrigated pepper plot.

The water level records (Fig. 5b, c, d) indicate a yearly signal with amplitude decreasing away from the river, from nearly $2 \mathrm{~m}$ at $\mathrm{P} 1$ to $1 \mathrm{~m}$ at P3 and Bagara. The minimum level occurs near mid-July, just when the $K Y$ begins to flow while the maximum takes place in January when the KY stops flowing. The water level seems therefore controlled by the KY regime and not by rainfall. 
Gravity is sensitive to water level changes since it involves mass displacements. Gravity data are shown to provide a porosity estimate for an aquifer, when combined with water level measurements (Hinderer et al 2011). Here FG5 absolute gravity measurement gathered at Bagara (Fig. 5d) led to a porosity of 0.2 , however with a large uncertainty. Since the porosity estimate derived from the gravity measurements is the same that the one measured with MRS, it will be used as a strong constraint in further modeling.

a

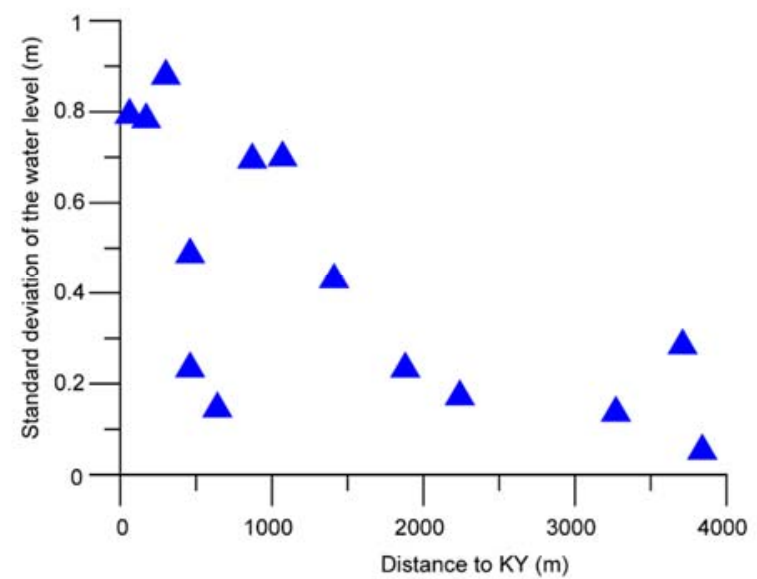

b

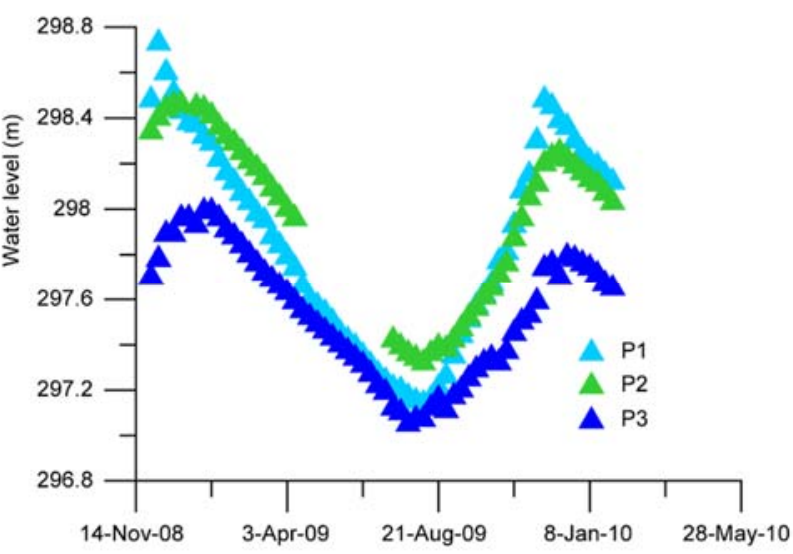

C

d

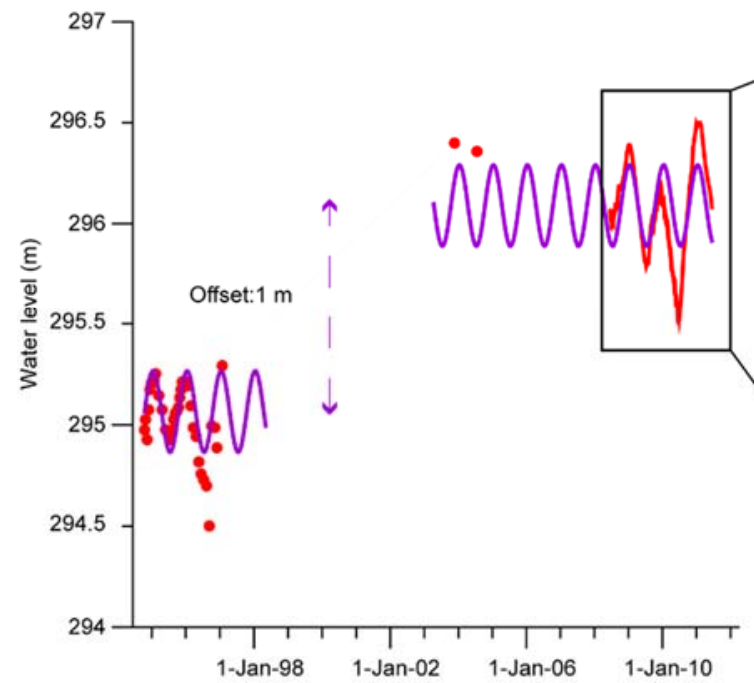

Fig. 5. Piezometric data near the KY; a: standard deviation of the water level in the different wells monitored by the "Direction de I'Hydraulique" as function of their distance to the KY; $\mathbf{b}$ : one year of piezometric measurement on the P1-P3 profile; c: data from the Bagara school well. The main sinusoidal interannual cycle is indicated in pink. Note the offset of about $1 \mathrm{~m}$ between 1996 and 2000; d: enlargement of the modeled period. Gravity data with the vertical scale are adjusted for a 0.20 porosity aquifer

\subsection{Recharge}

3.3.1 Available recharge estimates. The yearly recharge of this aquifer is a poorly constrained parameter. Isotopic data indicate a residence time of 1000 to $2000 \mathrm{yr}$ (Leduc et al. 2000). Adjustment of groundwater models led Leblanc (2002) and Gaultier (2004) to adopt a negative recharge - due to evapotranspiration - of a few $\mathrm{mm} / \mathrm{yr}$ on the Kadzell plain. However, the KY itself is considered as the main zone of recharge of the aquifer, with a mean estimated recharge rate of $1.2 \times 10^{6} \mathrm{~m}^{3} / \mathrm{yr}$ and a 
minor supply from Lake Chad of $0.2 \times 10^{6} \mathrm{~m}^{3} / \mathrm{yr}$ (Gaultier 2004). Recently, Le Coz et al. (2013) starting from the properties of superficial sediments (Le Coz 2011) proposed numerical modeling of infiltration and conclude that the infiltration rate below irrigated plots could amount to $0.3 \mathrm{~m} / \mathrm{yr}$. Numerous ponds, which consist mainly of abandoned meanders (Fig. 3) are filled by rainwater and water from the KY during the rainy season. Since their bed is mainly constituted by clay material, these ponds cannot take part to the recharge.

3.3.2 Vegetation uptake. Several species of tree and shrub of the Sahel have been shown to be able to extract groundwater up to several tens meter depth (Canadell et al 1996). These species include Prosopis juliflora, several Accacia species, Fahiderbia albida (gao) and Azardirachta indica (neem) which are common in the Diffa area. Various transpiration values, generally deduced from sap flow measurements have been reported in the literature for these species (Brenner et al 1991; Khanzada et al 1998; Roupsard et al. 1999) which have been averaged by us to $1.5 \mathrm{~mm} / \mathrm{d}$ under the canopy. For a tree coverage of $5 \%$ deduced from Google Earth images of this region this corresponds to a 0.075 $\mathrm{mm} / \mathrm{d}$ transpiration value. The tree coverage can be locally much more than $5 \%$, for example at the NE border of the city of Bagara, but we have checked that the groundwater models used here were sensitive to the tree coverage at the scale of the model rather to its local changes. Boronina and Ramillien (2008) deduced from AVHRR satellite data a much higher value of $0.5 \mathrm{~mm} / \mathrm{d}$ near Bagara during the dry season, however with a coarse resolution of $1 \mathrm{~km} \times 1 \mathrm{~km}$, which can be modified by the neighboring pixels located above the free water still remaining in a pond on the riverbed.

\section{Transient models of the quaternary aquifer}

\subsection{Modeling approach}

4.1.1. The conceptual model. The piezometric map shows that the $K Y$ is a major recharge zone for the quaternary aquifer and agriculture is concentrated in the KY valley, which led us to considered a conceptual model focused on the KY valley (Fig. 6a). According to this model, the quaternary aquifer is recharged at the bed of the $\mathrm{KY}$, and groundwater flow is directed symmetrically toward the two piezometric depressions located north and south. The quaternary aquifer is considered as a $50 \mathrm{~m}$ flat layer either with constant properties, or including a $2 \mathrm{~m}$ thick higher permeability basal layer. This aquifer overlies the Pliocene clays which are considered as unpervious. It is recharged by the KY at its axis. Given the lack of data on the riverbed properties, the relationship between the recharge flux $\mathrm{Q}_{\text {in, }}$, the altitude of the river surface $\mathrm{hr}$ and that of the water table $\mathrm{h}$, is kept as simple as possible, i.e. linear and characterized by a single river coefficient $C$ :

$$
\begin{array}{ll}
Q_{\text {in }}=C \times(h r-h b) & h<h b \\
Q_{\text {in }}=C \times(h r-h) & h>h b
\end{array}
$$

When the hydraulic head in the aquifer is below the river bed, the water flux is directed toward the aquifer and proportional to the height of the $K Y$ above its bed, while when the hydraulic head is above the river bed $Q_{i n}$ can be either positive or negative. Equation (2) allows therefore the aquifer to take part to the river discharge during low flow. The coefficient $\mathrm{C}$ is adjusted for each hydrologic year (Rushton 2007). This is clearly an approximation since the relationship between $Q_{i n}, h r$ and $h$ is known to be often nonlinear (Sophocleous 2000). Indeed, more sophisticated models of the river aquifer interaction are possible (Delft et al., 2011; Shanafield et al. 2012; Min et al. 2013), but they would require data which are not available in the context of data scarcity in the sahelian area.

A symmetry condition is assumed at the KY axis, which allows to consider only the northern border of the river. At the northern boundary of the model, the water table is not sensitive to yearly to decadal changes induced by the river (Fig. 4a), the hydraulic head is constant and the hydraulic gradient defines the flow escaping from the aquifer $Q_{\text {out }}$. A constant flux, $Q_{\text {evap }}$ is extracted from the aquifer by the vegetation according to the previous section.

4.1.3. Numerical model. The quaternary aquifer is modelled as $50 \mathrm{~m} \times 6.5 \mathrm{~km} \times 8 \mathrm{~km}$ horizontal volume including one or two different layer with a finite differences $100 \mathrm{~m} \times 100 \mathrm{~m}$ uniform grid (Fig. Fig. 6b). The equation of flow are solved with the Modflow open source package for which both the 
set of equations and the numerical resolution method can be found in (Harbaugh and McDonald 1996a, b). Pmwin provides a free user-friendly interface for Modflow (Chiang and Kinzelberg 2005). These softwares, as they can be freely distributed, are well suited for low income countries such as Niger.

The model is calibrated with 4 years of the KY daily water level observations, beginning in July 2007 and ending in June 2011. The 2008-2011 duration corresponds to our data coverage and the year 2007 is used to damp the difference between our initial condition and the actual head distribution. The model is calibrated against water levels observed at P2, P3 and Bagara, P1 being excluded, as it is located inside an irrigated plot. The following parameters are calibrated : the hydraulic conductivity and porosity of the aquifer, the river coefficient $\mathrm{C}$ for each hydrological year, and an offset between P1-3 and the riverbed corresponding to errors in the leveling surveys. First simulations with a no flow surface boundary condition were not able to reproduce the water level at the Bagara well, and especially the nearly $90 \mathrm{~mm}$ decrease between the minimum levels in July 2008 and July 2009. All models include therefore the vegetation uptake of $0.075 \mathrm{~mm} / \mathrm{d}$ discussed in section 3.3.

a

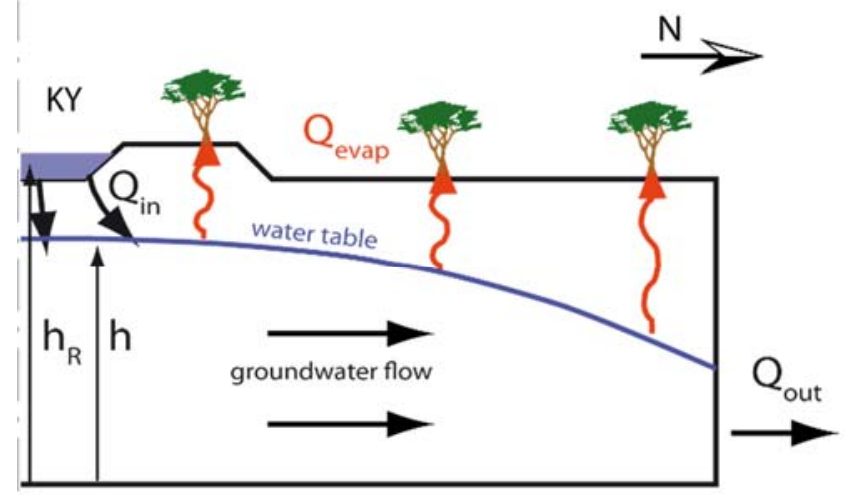

b

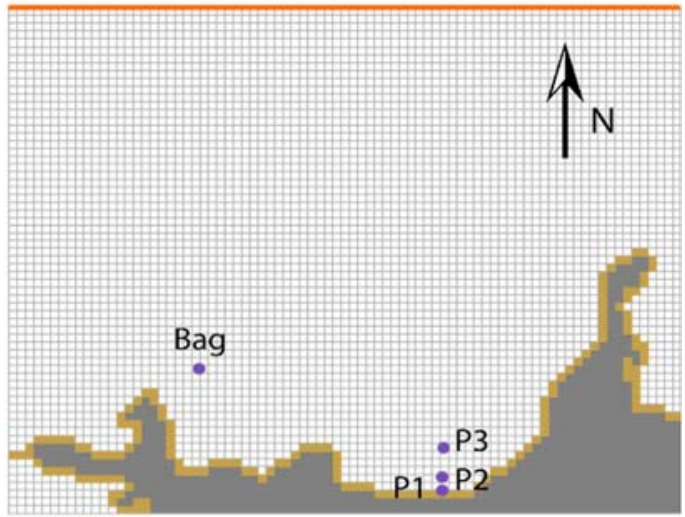

Fig. 6. The model. a: conceptual model drawn perpendicularly to the river axis. The river recharges the aquifer at its axis; water is extracted from groundwater by sahelian vegetation and the slope of the water table defines the flux escaping at the northern boundary. b: the finite difference grid with a $100 \mathrm{~m}$ uniform grid spacing in both direction. The river is at the base of the grid (in light brown) and the grey area at the base of figure is not modeled. The orange line is the northern boundary condition.

\subsection{Adjustment of model parameters}

First models with a constant hydraulic conductivity led to a value of $4.310^{-4} \mathrm{~m} / \mathrm{s}$ (see Online Resource 2 ), i.e. at least one order of magnitude larger than previous estimates derived from large scale groundwater models of this area, unrealistic for silty sediments and more than one order larger than the estimate obtained by Le Coz et al. (2010) for superficial sediments. This led us to suspect that this high permeability was partly standing for the coarse sand layer observed at the base of several boreholes and for the higher permeability zones deduced by Descloitres et al. (2013) from MRS data. Then, the refined model with a $2 \mathrm{~m}$ thick basal high permeability layer is adopted. The adjusted permeabilities are $1.710^{-5} \mathrm{~m} / \mathrm{s}$ and $10^{-2} \mathrm{~m} / \mathrm{s}$, for the upper and lower layers. The porosity is 0.2 and the river coefficients are $10,8.7,7.6$ and $12 \times 10^{-6} \mathrm{~m} / \mathrm{s}$ for the years $2007-2008$ to $2010-2011$ (Fig. 7). The standard deviation between measured and observed water levels is $0.12 \mathrm{~m}$. River coefficients display a good regression $\left(R^{2}=0.96\right)$ when plotted against the mean height of the river during the flow season, which gives some confidence on the physical consistency of the model and will allow to estimate the unknown C. The reader is referred to Online Resource 2 for a detailed comparison 
between the one layer and the 2-layer models, a validation of the model against previous data at the Assaga well and a sensitivity study on the model parameters. The sensitivity study shows that the error bars on either river coefficients or hydraulic conductivities were corresponding to a 1.6 multiplicative factor, i.e. that any variables, say $C_{0}$ should be considered within the $\left[0.4 \times C_{0}, 1.6 \times C_{0}\right]$ uncertainty range.

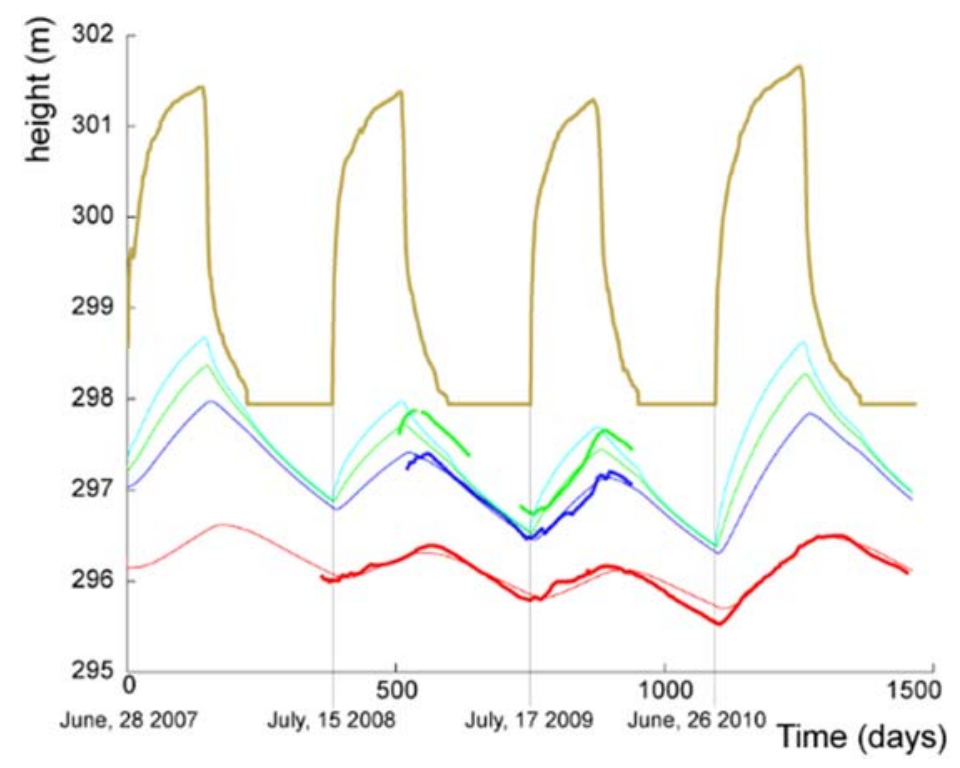

Fig. 7. Comparison of modeled (thin lines) and observed hydraulic heads (heavy lines) for the adjusted 2-layers model of the upper quaternary aquifer. The water level of the KY is in brown. Data from Bagara are in red and from $\mathrm{P} 2$ and $\mathrm{P} 3$ in green and blue, respectively. The hydraulic head in the aquifer at the $\mathrm{KY}$ axis is indicated by the curve in cyan. The adjusted parameters are: $\mathrm{K}=1.710^{-5} \mathrm{~m} / \mathrm{s}$ for uppermost $48 \mathrm{~m}$ and $10^{-2} \mathrm{~m} / \mathrm{s}$ for the $2 \mathrm{~m}$ thick basal layer, $\phi=0.20, \mathrm{C} 1-4=10,8.7,7.6$, and $12 \times 10^{-6} \mathrm{~m} / \mathrm{s}$. The standard deviation between modeled and observed hydraulic heads is $0.12 \mathrm{~m}$

\subsection{Effect of recharge under irrigated plots.}

Part of the irrigation water returns to the aquifer under irrigated plots, especially since they are located near the river where the water level is only a few meters below the surface. We have therefore included a $0.3 \mathrm{~m}$ yearly recharge, which is the mean recharge given by Le Coz et al. (2013). This recharge was assumed to take place at a constant rate during the irrigation period, i.e. during 7 months between mid-June and mid-January. This distribution in time of the recharge could be easily refined, taking into account both the results of Le Coz et al. (2013) and the agricultural calendar for pepper exposed in the Online Resource 1. The additional recharge is assumed to occur below a 200 $\mathrm{m}$ band along the KY, which was measured on the different images provided by Google Earth. Extrapolating these $200 \mathrm{~m}$ on both banks of the $\mathrm{KY}$ and on a length of $150 \mathrm{~km}$ of the KY between Tam and Bosso will result in a 6000 ha irrigated pepper surface, which roughly correspond to the estimate given in Online Resource 1. Simulations from the resulting adjusted model show similar agreement with data as the model with no infiltration (standard error $=0.12 \mathrm{~m}$ ) with the following river coefficients $9.3,5.9,5.8,9.4 \times 10^{-6} \mathrm{~ms}^{-1}$, and a $3 \mathrm{~cm}$ change in the adjusted leveling error. The adjusted porosity and permeabilities were the same as those of the previous section. Interestingly, the only changed parameters are those which directly control the infiltration rates, i.e. the river coefficients. The mean difference of $20 \%$ between the infiltration coefficients suggests that the irrigation recharge would represent nearly $20 \%$ of the volume infiltrated from the KY. Hence the infiltration budget of the river is not significantly changed by the introduction of infiltration, since there is $20 \%$ less infiltration at the river axis but $20 \%$ additional infiltration along the $200 \mathrm{~m}$ irrigated band. Given the minor effect introduced by irrigation return flow on the water budget, we did not attempt to model more precisely the distribution in time of this recharge. 


\subsection{Implications for the water budget of the $\mathrm{KY}$ and of the quaternary aquifer.}

The annual uptake from the KY due to infiltration through its bed can be estimated from the river coefficients adjusted in our models. For each kilometer, the infiltration uptake is $0.87 \times 10^{6} \mathrm{~m}^{3} / \mathrm{yr}$ for the 2010-2011 wet year, and $0.53 \times 10^{6} \mathrm{~m}^{3} / \mathrm{yr}$ for the $2009-2010$ driest year in our $4 \mathrm{yr}$ simulation period. Considering that the distance between Tam at the entry of the KY in Niger and Bosso at its mouth is nearly $150 \mathrm{~km}$ and extrapolating our results over this distance would predict an infiltration uptake on the northern rim of the KY of $130 \times 10^{6} \mathrm{~m}^{3} / \mathrm{yr}$ for a humid year and of $79 \times 10^{6} \mathrm{~m}^{3} / \mathrm{yr}$ for a dry year. This constitutes a significant part of the total discharge of the river, comprised between 400 and $900 \times 10^{6} \mathrm{~m}^{3} / \mathrm{yr}$ for the last ten years. These results seem reasonable with respect to the decrease of discharge commonly observed for the KY between Tam and Bosso. However the lack of continuous datasets at these hydrological stations does not allow to confirm the infiltration balance of the KY from discharge data. It should therefore be considered that these estimates suffer from a $60 \%$ uncertainty resulting from the uncertainty on the river coefficients themselves (see Online Resource 2). The annual abstraction by irrigation can be roughly estimated by considering a total irrigated surface of $6000 \mathrm{ha}$, with an annual water need of $600 \mathrm{~mm}$ identical to that of sweet pepper (Dorrendos and Kassam 1979). This would require an annual uptake of $36 \times 10^{6} \mathrm{~m}^{3} / \mathrm{yr}$, which is still negligible with respect to the total discharge of the KY. However, this constitutes a significant part of the water infiltrated from the KY.

These estimates are several orders of magnitude larger than those of Gaultier (2004) $\left(1.2 \times 10^{6} \mathrm{~m}^{3} / \mathrm{yr}\right)$ or even Leduc-PNUD (1991) $\left(5 \times 10^{6} \mathrm{~m}^{3} / \mathrm{yr}\right)$ and Leblanc (2002) $\left(6.5 \times 10^{6} \mathrm{~m}^{3} / \mathrm{yr}\right)$. However, they are consistent with the $1.6 \mathrm{~m} / \mathrm{km}$ observed slope of the water table in the quaternary aquifer; the difference between the present model and the previous ones relies on the adopted permeability in the aquifer. As in the previous model, the permeability was constrained by the need to sustain the piezometric depression in the Kadzell, it seems that the permeability values obtained here hold for $\mathrm{KY}$ valley only and not for the whole Kadzell area.

\subsection{Tentative extrapolation for future scenarios for the KY regime}

Assessing the consequences of climatic changes should include wet years and dry years given the uncertainties on climatic models for the region (Druyan 2011). We forced therefore the model with 5 humid years, which are modeled as the 2010-2011 year, followed by five dry years modeled as the 1973-1974 year, and again 5 humid years. The 1973-1974 hydrological year is the driest one for which quantitative detailed data are available. The river coefficient for 2010-2011 is the adjusted one, while the 1973-1974 one has been obtained by extrapolation from the linear relationship between adjusted river coefficients and the mean height of the KY during its flow season. This leads to a $3.5 \times 10^{-6} \mathrm{~ms}^{-1}$ river coefficient.

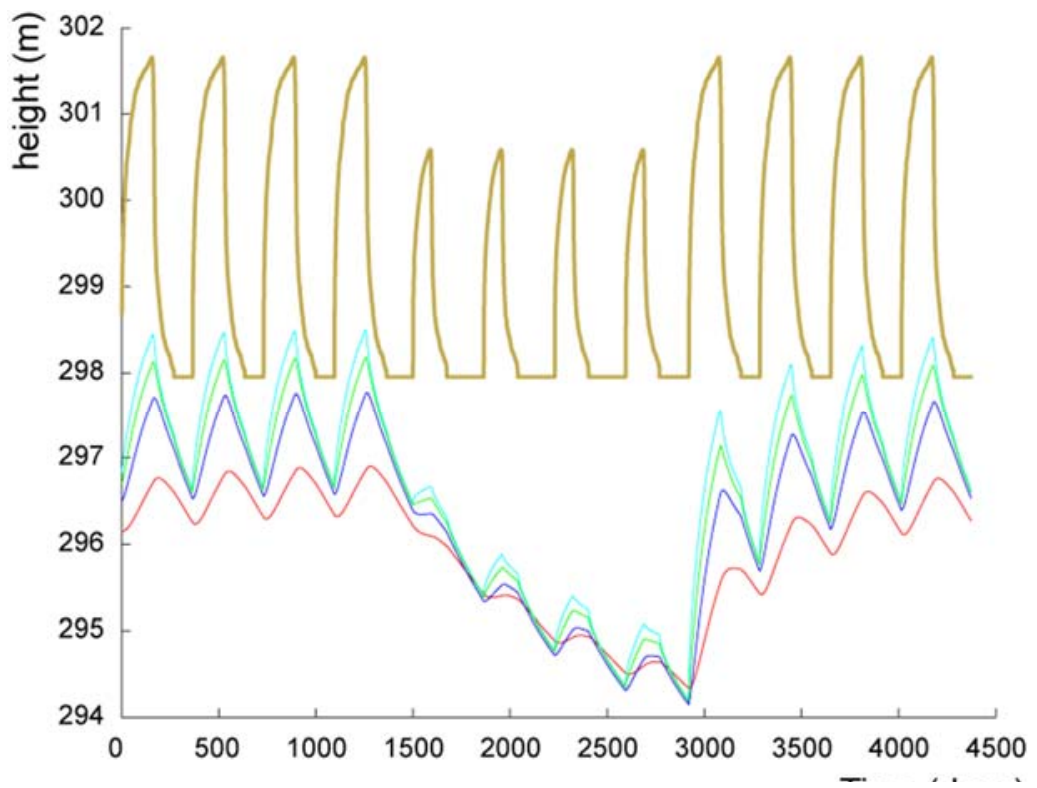

Fig. 8. Water level at the P1-3 and Bagara wells during a theoretical KY hydraulic regime change (upper brown curve). The color code of the curves is the same as in Fig. 7 
It is shown in Fig. 8 that five successive dry years resulted in a nearly $2 \mathrm{~m}$ drop of the water table near the KY axis. The hydraulic head at the river axis shows that water infiltrating from the KY must then flow through a $3 \mathrm{~m}$ unsaturated zone, for which the permeability could become extremely low and the river coefficient of $3.5 \times 10^{-6} \mathrm{~ms}^{-1}$ could be overestimated. However, the water table is able to recover almost completely after $5 \mathrm{yrs}$. It should be emphasized that these results are strongly dependent on the adopted river coefficient model and that using the river coefficient of the year 2010-2011 after the four dry year is probably an overestimate. If we consider that the river coefficient is controlled by the thickness of the non-saturated zone under the river, the coefficient of dry years should be kept for the wet years following the drought. In such case, the recovery of the groundwater level would be less than $1 \mathrm{~m}$ at the river axis and is nearly $0.5 \mathrm{~m}$ at the Bagara well. Hence there could be a serious risk for a permanent and irreversible drop-down of the groundwater storage. The river coefficient for $73-74$ is also poorly constrained, as it results from extrapolation. If we use instead the value of $7.6 \times 10^{-4} \mathrm{~m}^{2} \mathrm{~s}^{-1}$, which is the lowest adjusted river coefficient value, obtained for the much wetter year 2009-2010, the groundwater level drop is only 1 to $1.5 \mathrm{~m}$ near the $\mathrm{KY}$, and the recovery is almost complete after five wet years.

\section{Conclusion}

The Northern Sahel area generally lacks any active permanent hydrological network and groundwater constitutes there a key resource for development. Sensitivity of this resource to climate and to anthropic disturbances should be assessed to foster sustainable development. The KY area may serve as an example case due to its recent population growth and agricultural development in the immediate border of the river. It is shown here that even with scarce data the water budget of the river and the aquifer can be estimated from numerical modeling of groundwater flow.

The model relies on groundwater monitoring, mainly on a $1 \mathrm{yr}$ period, at various distances of the river. It is strengthened by exploration geophysics data, namely by TDEM and MRS. It requires in addition that an approximate piezometric map is available at a larger scale for providing boundary conditions. The model results rely on a poor data coverage, both in space and in time, which is a common situation in remote African regions. They should be therefore considered as first estimate to be refined as soon as further data are available.

The hydraulic head in the aquifer is lower than the water level in the KY during all simulations. As a consequence the quaternary aquifer is not able to sustain the low flow discharge of the KY. Nonreversible disconnection of the aquifer from the river could result from decreasing infiltration rates through an unsaturated porous medium of increasing thickness. The present water level in the aquifer shows however that the aquifer was able to catch up with the KY level after the drought of the $80 \mathrm{~s}$ and the 90s. The model proposed here indicates that this should also occur even after applying the 73-74 level of the KY during 5 successive years, although with large uncertainties resulting from the simplified aquifer/river coupling with a constant $C$.

During the study period, the infiltration from the $\mathrm{KY}$ toward the aquifer was between $160 \times 10^{6} \mathrm{~m}^{3} / \mathrm{yr}$ and $260 \times 10^{6} \mathrm{~m}^{3} / \mathrm{yr}$, which constitutes a significant part of the total discharge of the $\mathrm{KY}$, ranging from 400 to $900 \times 10^{6} \mathrm{~m}^{3} / \mathrm{yr}$. The total amount of water needed for irrigation of pepper plots can be estimated to $36 \times 10^{6} \mathrm{~m}^{3} / \mathrm{yr}$. This indicates that the present state of agricultural development is sustainable regarding the available amount of surface water and groundwater. Non sustainability may however arise due to exhaustion of soil or the persistence of pesticides or fertilizers in the environment.

Since major uncertainty relies on the coupling between the river and the aquifer we suggest focusing further studies on this topic. A series of ponds remain in the riverbed after the flow season. Their connection with the aquifer can be questioned given the importance of these ponds for irrigation after the flow season. Moreover recharge of the aquifer could be optimized with small dams. To further generalize the method applied here to the KY valley, we suggest that integrated water 
resource management in the Sahelian area should consider the role of temporary rivers, and should involve data gathering and analysis on their immediate surroundings.

Aknowledgements : The research presented in this paper has been funded by the Ghyraf ANR project, the REPAS CNRS/INSU EC2CO project and the IRD LAC TCHAD project. Nathalie Rouche is thanked for her help with the SIEREM database, François Delclaux for kindly providing the rainfall data, Gilbert Ferhat for his help with the leveling, Mathieu le Coz for sharing his experience on the permeability of the KY aquifer, and the whole IRD team in Niamey for logistic support.

\section{References:}

Babamaaji RA, Lee J (2014) Land use/land cover classification of the vicinity of Lake Chad using NigeriaSat-1 and Landsat data. Env Earth Sci. doi 10.1007/s12665-013-2825-x

Barbier BE (2003) Upstream dams and downstream water allocation; the case of the Hadejia-Jama'are floodplain, northern Nigeria. Wat Res Res. doi:10.1029/2003WR002249

Bastola S, Delclaux F (2011) Temporal extension of meteorological records for simulation modeling of Lake Chad Basin (Africa) using satellite rainfall data and reanalysis datasets. Meteo Apl. doi: 10.1002/met.257

Boronina A, Ramillien G (2008) Application of AVHRR imagery and GRACE measurements for calculation of actual evapotranspiration over the Quaternary aquifer (Lake Chad basin) and validation of groundwater models. J of Hydrol 348: 98-109

Boyer JF, Dieulin C, Rouché N, Cres A, Servat E, Paturel JE, Mahé G (2006) SIEREM an environmental information system for water resources. $5^{\text {th }}$ World FRIEND Conference, La Havana - Cuba, November 2006, IAHS Publ 308: 19-25

Brenner AJ, Jarvis PG, Vandenbeldt RJ (1991) Transpiration from a neem windbreak in the Sahel. In: Soil water balance in the Soudano-Sahelian zone, Sivakumar, M.V., Wallace, J.S., Renard, C., Giroux, C. (Eds), IAHS Pub 199: 375-386

Canadell J, Jackson RB, Ehleringer JB, Mooney HA, Sala OE, Schulze ED (1996) Maximum rooting depth of vegetation types at the global scale. Oecologia 108: 583-595

Candela J, Elorza FJ, Tamoh K, Jimenez-Martinez J, Aureli A (2013) Groundwater modelling with limited data sets: the Chari-Logone area (Lake Chad Basin, Chad). Hydrol Processes. doi: 10.1002/hyp.9901

Carter RC, Alkali AG (1996) Shallow groundwater in the northeast arid zone of Nigeria. Quat J Eng. Geol 29: 341345

Cheo AE, Voigt H-J, Mbua RL (2013) Vulnerability of water resources in northern Cameroon in the context of climate change. Env. Earth Sci., 70, 1211-1217. doi: 10.1007/s12665-012-2207-9

Chiang WH, Kinzelbach W (2005) 3D-groundwater modeling with Pmwin, a simulation system for modeling groundwater flow and transport processes. Springer, Berlin

Delft J-O, Blumensaat F, Wang W, Krebs P, Kolditz O (2011) Coupling hydrogeological with surface runoff model in a Poltva case study in Western Ukraine. Env. Earth Sci., 65, 1439-1457. doi: 10.1007/s12665-011-1285-4.

Descloitres M, Chalikakis K, Legchenko A, Moumouni A, Genthon P, Favreau G, Le Coz M, Boucher M, Oï M (2013) Groundwater resources estimation using MRS and electromagnetic surveys in the Komadugu Yobe valley, Lac Chad area, Niger. Afr J Earth Sci. doi: 10.1016/j.jafrearsci.2013.07.006

Doorenbos J, Kassam AH (1979) Réponse des rendements à l'eau. FAO Bul. Irrig. Drainage, 33, FAO, Rome, Italy,193 p.

Druyan LM (2011) Review of studies of $21^{\text {th }}$-century precipitation trends over West Africa. Int J Climatol 31: 1415-1424. doi:10.1002/joc.2180

Engelhart I, Raush R, Keim B, Al-Saud M, Shcuth C (2013) Surface and subsurface conceptual model of an arid environment with respect to mid- and late Holocene climate changes, Env Earth Sci. doi: 10.1007/s12665013-2303-5

Eberschweiler C (1993) Monitoring and management of groundwater resources in the Lake Chad Basin: mapping of aquifers water resource management - final report. R 35 985, CBLT - BRGM, Orleans, France

Edmunds WM (2009) Paleoclimate and groundwater evolution in Africa: implications for adaptation and management. Hydrol Sci J 54: 781-792

Feng SY, Huo ZL, Kang SZ, Tang ZJ, Wang FX (2011) Groundwater simulation using a numerical model under different water resources management scenarios in an arid region of China, Env Earth Sci. doi:10.1007/s12665-010-0581-8 
Fitterman DV, Stewart MT (1986) Transient electromagnetic sounding for groundwater. Geophysics 51: 9951005

Gaultier G (2004) Recharge et paléo-recharge d'une nappe aquifère libre en milieu sahélien (Niger Oriental). Approches géochimiques et hydrodynamiques, Thesis, Univ. PXI, Paris

Guérin R, Descloitres M, Coudrain A, Talbi A, Gallaire R (2001) Geophysical surveys for identifying saline groundwater in the semi-arid region of the central Altiplano, Bolivia. Hydrol Process 15: 3287-3301. doi: 10.1002/hyp.284

Greigert J (1979) Atlas des eaux souterraines de la République du Niger. Etat des connaissances (Mai 1978), rapport 79 AGE 001: 218-284, BRGM, Orléans, France, available for downloading at : http://infoterre.brgm.fr/rapports/79-AGE-001.pdf, last accessed 2014/03/16

Gumnior M, Preusser F (2007) Late Quaternary river development in the southwest Chad Basin : OSL dating of sediments from the Komadugu paleoflooplain (Northeast Nigeria). J Quat Sci 22: 709-719. doi: 10.1002/jsq.1091

Hargbauh AW, McDonald MG (1996a). User's documentation for MODLFOW-96 an update to the U.S. Geological Survey finite difference groundwater flow model. Open-File report 96-485, U.S. Geological Survey

Hargbauh AW, McDonald MG (1996b) Programmer's documentation for MODFLOW-96 the U.S. Geological Survey finite difference groundwater flow model, Open-File report 96-486, U.S. Geological Survey

Hinderer J, Pfeffer J, Boucher M et al. (2011) Land water storage from ground and space geodesy; firsts results from the GHYRAF (Gravity and Hydrology in Africa) experiment. Pure Appl Geophys. doi: 10.1007/s00024011-0417-9

Hulme M (2001) Climatic perspectives on Sahelian dessiccation: 1973-1998. Glob Environ Change 11: 19-29

IWACO (1985) Etude des ressources en eau du bassin de la Komadougou Yobe, commission nigero-nigerienne de coopération, Niamey.

Khanzada AN, Morris JD, Ansari P, Slavich PG, Collopy JJ (1998) Groundwater uptake and sustainability of acacia and prosopis plantations in southern Parkistan. Agr Wat Manag 36: 121-139

Lebel T, Ali A (2009) Recent trends in the Central and Western Sahel rainfall regime (1990-2007). J of Hydrol 375: $52-64$

Leblanc M (2002) Use of GIS and remote sensing for water resources management of large semiarid regions. A case study of the Lake Chad Basin, Africa. PhD Thesis, University of Glamorgan (UK) and Poitiers University (Fr)

Leblanc JM, Favreau G, Maley J, Nazoumou Y, Leduc C, Stagnitti F, Van Oevelen PJ, Delclaux F, Lemoalle J (2006) Reconstruction of Megalake Chad using shuttle radar topographic mission data. Palaeogeog Palaeoclimatol Palaeoecol 239: 16-27

Leduc C, Salifou O, Leblanc M (1998) Evolution des resources en eau dans le département de Diffa, Bassin du Lac Tchad, Est Niger. In: Water Resource Variability in Africa during the XXth century, E Servat ,D Hughes, JM Fritsch and M Hulme (Eds) IAHS Pub 252: 281-288

Leduc C, Sabljak S, Taupin J.D, Marlin C, Favreau G (2000) Estimation de la recharge de la nappe quaternaire dans le nord-ouest du bassin du lac Tchad (Niger oriental) à partir de mesures isotopiques. C R.Acad Sci Paris II a 330: 355-361

Leduc-PNUD (1991) Les ressources en eau du département de Diffa, Diffa, Direction de I'Hydraulique, Projet PNUD/DCTCD/NER/86/001

Le Barbé L, Lebel T, Tabsoba D (2002) Rainfall variability in West Africa during the years 1950-90. J of Climate 15: 187-202

Le Coz M (2010) Modélisation hydrogéologique de dépôts hétérogénes: I'alluvium de la Komadougou Yobé, bassin du Lac Tchad, PhD Thesis, Univ. Montpellier II, France, downloadable at http://www.hydrosciences.org/IMG/pdf/These_MathieuLeCoz_2010.pdf, last accessed 2014/05/16

Le Coz M, Genthon P, Adler PM (2011) Multiple-point statistics for modeling facies heterogeneities in a porous medium: the Komadugu-Yobe alluvium, Lake Chad Basin. Math Geosci. doi: 10.1007/s11004-011-9353-6

Le Coz M, Favreau G, Ousmane DS (2013) Modeling increased groundwater recharge due to change from rainfed to irrigated cropping in a semiarid region. Vadose Zone J. doi:10.2136/vzj2012.0138

Legchenko A, Baltassat JM, Beauce A, Bernard J (2002) Nuclear magnetic resonance as a geophysical tool for hydrogeologists. J Appl Geophys. doi: 10.1016/S0926-9851(02)00128-3

Luxereau A, Genthon P, Ambouta Karimou JM (2011) Fluctuations in the size of Lake Chad: consequences on the livelihoods of the riverain peoples in eastern Niger. Reg. Environ. Changes. doi: 10.1007/s10113-0110267-0 
Mahé G, Paturel JE (2009) 1896-2006 sahelian rainfall variability and runoff increase of sahelian rivers. C R Geosciences 341:538-546

Martinson J (2010) Change in the course of the river Komadugu Yobe during the 20th century at the border between Niger and Nigeria, Master Thesis, Lund University, UK, downloadable at http://lup.lub.lu.se/luur/download?func=downloadFile\&recordOld=1546003\&fileOId=1546009, last accessed 2014/05/16

MacDonald AM, Bonsor HC, Dochartaigh BE, Taylor RG (2012) Quantitative maps of groundwater resources in Africa. Environ Res Lett. doi:10.1088/1748-9326/7/2/024009

Min LL, Yu JJ, Liu CM, Zhu JT, Wang P (2013) The spatial variability of streambed vertical hydraulic conductivity in an intermittent river, northwestern China, Env Earth Sci. doi: 10.1007/s12665-012-1973-8

Mortimore MJ, Adams WM (2001) Farmer adaptation, change and 'crisis' in the Sahel. Glob Env Change 11: 4957

Mortimore M (2010) Adapting to drought in the Sahel: lessons for climate change. WIRES Climate Change $1: 134-143$

Olivry JC, Chouret A, Vuillaume G, Lemoalle J, Bricquet JP (1996) Hydrologie du lac Tchad. IRD, Paris

Roupsard O, Ferhi A, Granier F, Depommier D, Mallet B, Joly HI, Dreyer E (1999) Reverse phenology and dryseason water uptake by Faidherbia Albida (Del.) A. Chev. in an agroforestry parkland of Sudanese west Africa. Funct Ecology. doi: 10.1046/j.1365-2435.1999.00345.x

Rushton K (2007) Representation in regional models of saturated river-aquifer interaction for gaining/losing rivers. J of Hydrol 334: 262-281. doi:10.1016/j.jhdyrol.2006.10.008

Scanlon BR, Keese KE, Flint AL, Gaye CB, Edmunds M, Simmers I (2006) Global synthesis of groundwater recharge in semiarid and arid regions. Hydrol Proc 20: 3335-3370

Schneider JL, Wolff JP (1992) Carte géologique et cartes hydrogéologiques au 1/1 500000 de la République du Tchad, mémoire explicatif, BRGM 209. BRGM, Orléans, France

Shanafield M, Cook PG, Brunner P, McCallum J, Simmons CT (2012) Aquifer response to surface water transience in disconnected streams. Wat Res Res. doi:10.1029/2012WR012103

Sophocleous M (2000) Interactions between groundwater and surface water: the state of the science. Hydrogeol J 10:52-67

Tarhule A, Woo MG (2002) Adaptation to the dynamics of rural water supply from natural sources: a village example in semi-arid Nigeria. Mit Adapt Stateg Glo Cha 7: 215-237

Taylor RG, Koussis AD, Tindimugay C (2009) Groundwater and climate in Africa-a review. Hydrol Sci J 54: 655664

UNESCO-PNUD-CBLT (1972) Study of water resources in the Lake Chad Basin 1966-1970. TR/ UNESCO/ UNDP/REG 71. UNESCO, Paris

Zairi R (2008) Etude géochimique et hydrodynamique de la nappe libre du Bassin du Lac Tchad dans les régions de Diffa (Niger=oriental) et du Bornou (nord-est du Nigeria). PhD Thesis Univ. Montpellier II, France, downloadable at http://www.hydrosciences.org/spip.php?article648, last accessed 2014/05/13 


\section{ONLINE ResourCE 1}

\section{LIFESTYLE OF POPULATIONS AND ACCESS TO WATER}

\section{Change of livelihood with the Drought}

More than $60 \%$ of the inhabitants of the Eastern Niger area are sedentary kanuri-speaking farmers and fishers. The livelihood of local populations is controlled by access to water: the north is devoted to herding, while in the south rainfed and irrigated agriculture are practiced with uncertain yield due to the large interannual rainfall variability of the Sahel climate. Before 1975, i.e. before the drought, the populations living on the border of the Lake Chad and the KY enjoyed a privileged situation where both fishing and irrigated farming were practiced in addition to rainfed agriculture. The main activity was fishing, which provided both a healthy food and cash income from sales of dried or smoked fish in Nigeria. Big fishes from the Lake Chad could also be found in the KY up to Tam. Rainfed pearl millet was farmed on sandy soils and irrigated farming was restricted to the lowlands near the Lake Chad and in the KY valley; onions, local eggplants, barley and wheat were grown. Rice was grown on clayey soils in the lowest plots, which were naturally flooded. Recession flood farming involved kassava, sweet potatoes, sorghum, cowpeas, squash and cucumbers. However, farming was a minor occupation and fishing was the main pillar of the local economy. Rainfed agriculture severely decreased since the drought and presently only $20 \%$ of the food needs are now covered (USAID FEWS Net Project, 2005). Despite the fact that local early varieties such as moro (80-90 days cycle) or buduma (60 days cycle) are cultivated, pearl millet farming has progressively receded. Fishing is now restricted to the (rare) years when the Lake Chad returns in Niger and in some villages such as Bosso and Tam. Moreover, the diversity and size of fishes have severely decreased. While rice, sorghum and cowpeas persist, these crops are of minor importance. Today, irrigated sweet pepper is the main source of income in the region and the so-called "red gold" induces a relative wealth in the Diffa region, where the poverty rate was close to $18 \%$ in 2010 against $60 \%$ in the whole Niger (Rep. du Niger, 2010).

\section{The success story of sweet pepper cropping in the $K Y$}

Irrigated sweet pepper is a new crop which was introduced by local traders from Nigeria in the Eastern Diffa region in 1955-1956. Thanks to well-known ancient irrigation techniques, it was adopted rapidly as a minor cash crop. Its geographical extension was limited until 1985, when the government of Niger and NGOs began to develop small irrigation programs. Then the pepper crop extended eastwards in the KY valley, reached Bosso in the 1990s and began recently to be cultivated on the Lake Chad shore. It is now estimated that pepper covers between 4000 and 8000 ha (nearly $65 \%$ of the total irrigated area) and provides work for at least 25000 people. Almost every inhabitant of the borders of the KY, including migrant farmers and a noticeable part of the urban population (and even employees of the state, of the local administration and of NGOs) is involved in producing, transforming or trading pepper. The annual yield is estimated to be $10000 \mathrm{t}$ corresponding to a total income to 5 to 6 billion FCFA (0.76 to $0.91 \mathrm{M}$ ) by Prêt and Konaté (2005), AUDEC (2006) and Barhouni et al. (2006). The cropping calendar is governed by the KY: pepper is sewed in nursery 40 days before the estimated arrival of the $K Y$ and is watered by rain and by irrigation until transplantation, which occurs at the actual arrival of the river, in June-July in Tam and later during July in Bosso. This offers to the people of Tam the advantage of an early first harvest, which they usually sell quickly as fresh pepper (i.e. not dried). Afterwards, plants are irrigated according the growth of the plant and to the evapotranspiration rate ; twice a week after transplantation, up to 
once a day in October when temperature is at its maximum, once a week or less when the temperature declines until January. Irrigation uses motored pumps to convey water from the nearby river or from ponds located in its abandoned meanders. The pumps are placed on the border of the river and water is distributed to the different plots by a system of narrow earth canals. In order to limit water leakage by infiltration from these canals pepper plots are generally concentrated on a narrow band along the KY. However, some of them are located more than $1 \mathrm{~km}$ away and the farmers must use two motored pumps, one of them being installed at mid distance. It is generally estimated that irrigation needs of pepper amount to 500 to $600 \mathrm{~mm}$ (Dorrenbos and Kassam, 1979). Irrigation stops when the river stops flowing and harvesting has to stop soon when irrigation is not possible. There is less insecurity in places such as Diffa, where undulations of the river bed define permanent ponds, from which water can be pumped after the flow period of the KY. Their connection to groundwater is still to be assessed. Depending from the cultural calendar, the KY regime and the localization of the plot, 5 to 7 successive harvests are allowed and pepper is mostly dried and sold in Nigeria. Harvest operations are exclusively reserved for women, with compensation in pepper.

Sweet pepper can be very profitable; however producers are always at risk. In 2009, the KY stopped flowing at the end of December in Bosso, between the first and the second harvest. Furthermore, this crop requires an initial input of $0.8 \mathrm{Mcfa} / \mathrm{ha}(1220 €)$ for fertilizers, pesticides and gasoline for the motored pumps, for a gross income of $1.2 \mathrm{Mcfa} / \mathrm{ha}(1830 €)$, obtained later at the harvest. Income inequalities are partly based on quality and surface of the plots as well on the ability of the producers to mobilize saving to buy inputs. Poorest producers may be involved in cycle of successive loans which lead them to sell their plots and work for bigger land owners (Luxereau and Diara, 2009; Luxereau et al., 2011). Moreover after 25 years of intensive agriculture, plots near the river suffer from soil exhaustion, which requires more fertilizers, and from pest infestations which require chemical control; both expenditures can alter the budget of producers. Moreover fertilizers and pesticides can be harmful to groundwater. Finally, new lands, away from the KY are now converted to pepper, with water either collected from the river with a system of intermediate pumps and reservoirs or from boreholes drilled in the quaternary aquifer, with serious risks of soil salinization due to the higher content of dissolved species in groundwater.

\section{References}

AUDEC (2006) Etude du marché des produits agro-pastoraux de la région de Diffa. Banque Africaine de développement. Rep du Niger, PADL Diffa

Barhouni M, Toudou A, Dan Kintafo A (2006) Etude de marché des produits agro-pastoraux dans la région de Diffa. Rapport Final, Banque Africaine de développement, République du Niger, PADL Diffa

Doorenbos J, Kassam AH (1979) Réponse des rendements à l'eau. FAO Bul. irrig. drainage, 33, FAO, Rome

Luxereau A, Diarra M (2009) Changement social et produits localisés au Niger. Colloque UNESCO Localiser les produits, une voie durable au service de la diversité naturelle et culturelle des Suds, Paris, 06/2009.

Luxereau A, Genthon P, Ambouta Karimou JM (2011) Fluctuations in the size of Lake Chad: consequences on the livelihoods of the riverain peoples in eastern Niger. Reg. Environ. Changes. Doi: 10.1007/s10113-011-02670

Prêt JF, Konaté S (2005) Etude sur l'impact de la production et de commercialisation du poivron dans les revenus des ménages de la région de Diffa. Dispositif National de Prévention et de gestion des Crises Alimentaires - Système d'information sur les marchés agricoles (SIMA), Diffa

Rep. du Niger (2010) Annuaire statistique des 50 ans d'indépendance du Niger, Institut National de la Statistique, Niamey.

USAID -Fews Net Projet (2005) Niger Livelihood Profiles. USAID Niamey. 


\section{OnLine Resource 2}

\section{SUPPLEMENTARY MATERIAL ON MOdel AsSESSMENT}

\section{Results obtained with a one-layer model}

First simulations were aimed at assessing the sensitivity of our observations to the different model parameters. This led us to choose to invert the following parameters: the permeability and porosity of the aquifer ( $K$ and $\varphi$ ), river coefficients at the bottom of the river for each hydrological year, and an offset corresponding to the leveling error between P1-3 and the riverbed. The best fitting model (Fig. OR2.1) was obtained with the Fmincon optimization function of Matlab ${ }^{\circledR}$ and the rms of the difference between modeled and observed water level values at P2, P3, and Bagara as objective function. We have also verified that our results were not dependent on the optimization method by checking also least squares and thermal annealing with similar results. The stability of the solution was checked by adding a random gaussian noise of standard deviation of $0.1 \mathrm{~m}$ to the data.

The maximun water level at the end of 2008 was hardly reproduced either on P2, P3 and Bagara. This could be a consequence of errors in the initialization of the model and could only be improved in future models if longer time series become available. Moreover, it was difficult to fit simultaneously Bagara P2 and P3, and even P2 and P3 simultaneously. This was interpreted as an effect of the simplifications introduced in the models. In particular, it appears in Fig. OR2.1 that the simulated water level in P3 and especially in P2 is similar in shape to the KY height curve, which is a consequence of the simulation of infiltration at the riverbed with a single river coefficient. Other sources of errors arise from heterogeneities in the riverbed and in the permeability field. The modeled hydraulic head at the river axis remains below the riverbed during most of the simulation time. This indicates that infiltration occurs through a non-saturated zone of variable thickness for which the transport properties are poorly accounted for by a single coefficient since processes in the vadose zone are known to be non-linear. The adjusted river coefficient commensurate with the mean level of the KY.

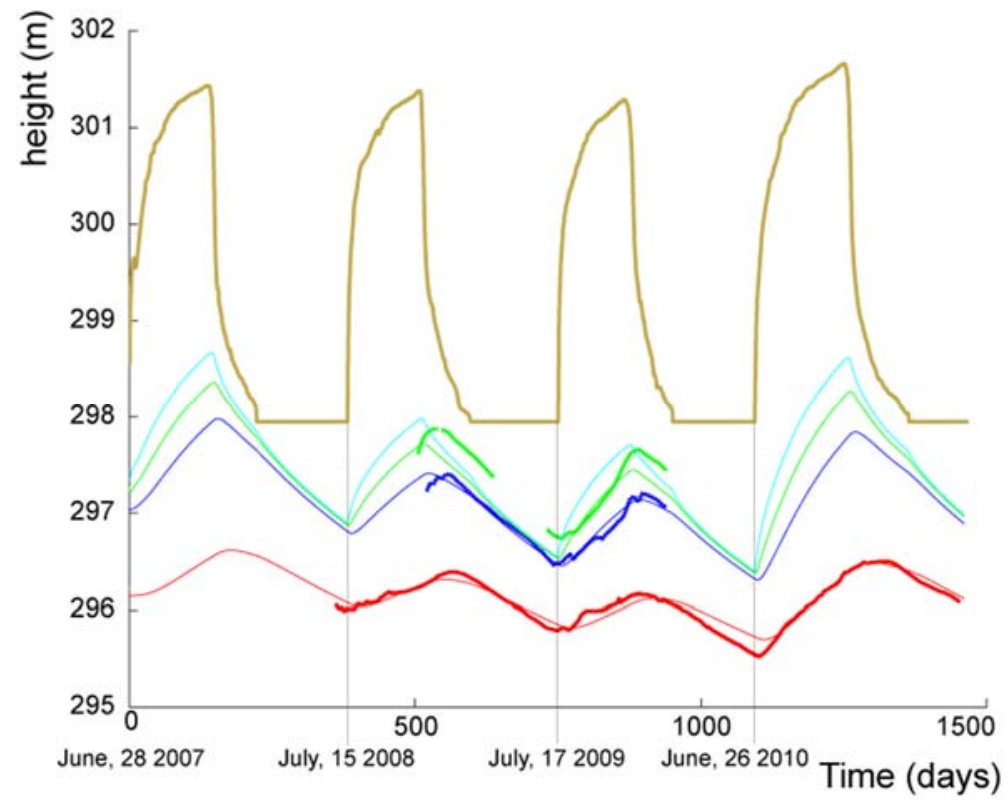

Fig. OR2.1 Comparison of modeled (thin lines) and observed hydraulic heads (heavy lines) for uniform permeability of the upper quaternary aquifer. The water level of the $\mathrm{KY}$ is in brown. Data from Bagara are in red and from P2 and P3 in green and blue, respectively. The hydraulic head at the KY axis is indicated by the curve in cyan. The adjusted parameters are: $\mathrm{K}=4.310^{-4} \mathrm{~m} / \mathrm{s}, \boldsymbol{\phi}=0.20, \mathrm{C} 1-4=9.6,6.4,6.1$, and $10 \times 10^{-6} \mathrm{~ms}^{-1}$, 
with an offset for P1-P3 of $-0.58 \mathrm{~m}$. The standard deviation between modeled and observed hydraulic heads is $0.12 \mathrm{~m}$.

\section{Sensitivity study}

There is a strong coupling between hydraulic conductivity and the river coefficients as shown in equation (1), assuming that the Dupuit approximation is valid, the river follows a straight line and that the aquifer is at steady state:

$$
\frac{\partial h}{\partial x}=C H / K
$$

where $\mathrm{x}$ is the coordinate perpendicular to the river axis, $\mathrm{h}$ is the hydraulic head, $\mathrm{C}$ is the river coefficient at the riverbed, $\mathrm{H}$ the mean height of the river above the water level in the aquifer $(\mathrm{CH}$ is therefore the flux of water introduced into the aquifer by the river) and $\mathrm{K}$ is the hydraulic conductivity of the aquifer. It results that the $\mathrm{C} / \mathrm{K}$ ratio, only can be inversed from $\frac{\partial h}{\partial x}$. A sensitivity study has therefore been achieved, starting from the case of Fig. OR2.1. Fig. OR2.2 shows the ratio of the actual objective function by the minimal objective function of the case of Fig. OR2.1 as a function of the Log of the hydraulic conductivity and the Log of river coefficients. In this figure, all four $C$ coefficients of Fig. OR2.1 are multiplied by the same value. If our case study was fully depicted by equation (1), the line $C / K=1$ would correspond to the value 1 . Fig. OR2.2 displays in contrast an ellipsoid shaped minimum with maximum elongation along the $C / K=1$ line. The dark blue area corresponds to $f / f_{0}<2$, and allows a 1.6 ratio either on $C$ or on $K$. Estimating that $f / f_{0}=2$ clearly exceeded the limit of a reasonable adjustment of the data led us to consider that our permeability and infiltration coefficients were determined within a 1.6 multiplicative factor.

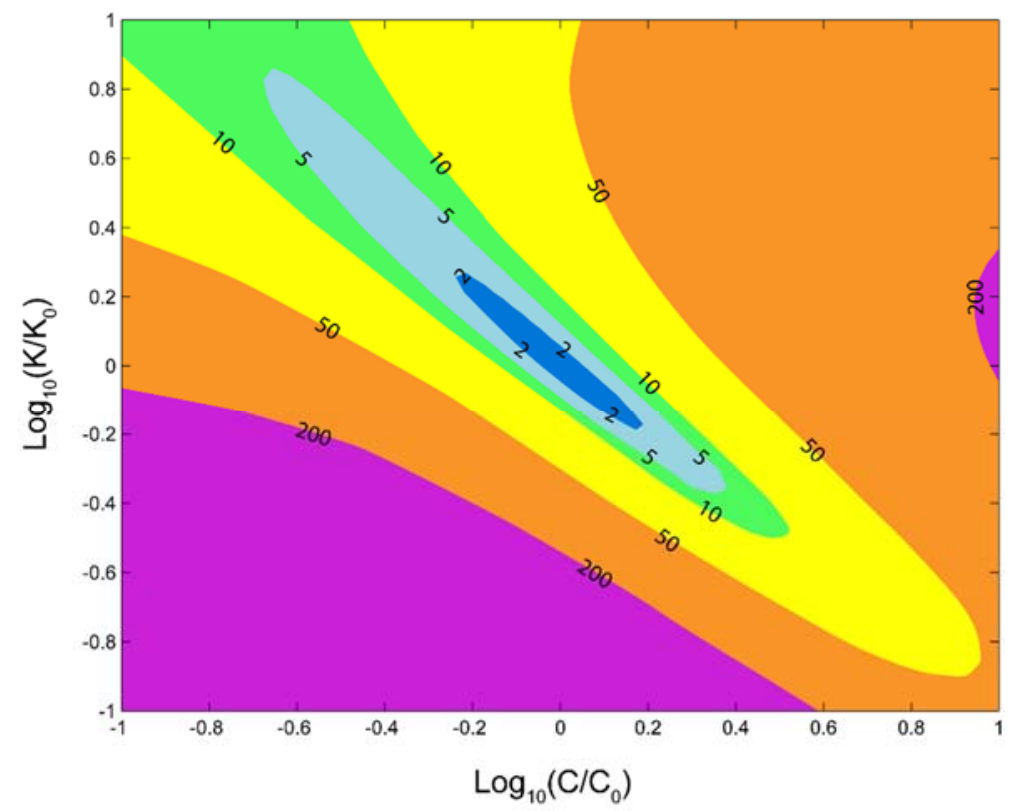

Fig. OR2.2. Sensitivity of the optimized solution to the hydraulic conductivity and the infiltration coefficients. The ratio of the actual objective function over the one of the case of Fig. OR2.1 is pictured as a function of the multiplicative factors of the hydraulic conductivity and infiltration coefficients The values of $C_{0}$ and $K_{0}$ refer respectively to the hydraulic conductivity and infiltration coefficients of the case of Fig. OR2.1. All the infiltration coefficients are multiplied by the same value.

\section{Two layers versus one layer}


The adjusted hydraulic conductivity value for the one layer model of section 1 is one order of magnitude larger than previous estimates derived from large scale groundwater models of this area and unrealistic for silty sediments. It is also more than one order larger than the $1.210^{-5} \mathrm{~m} / \mathrm{s}$ value obtained for the hydraulic conductivity of the superficial sediments from infiltration experiments with simulated rainfall (Le Coz, 2010). This led us to suspect that this high hydraulic conductivity was partly standing for the coarse sand layer observed at the base of several boreholes and for the higher permeability zones deduced by Descloitres et al. (2013) from MRS data. This led us to additional runs with a 2-layer sedimentary structure.

As a rule of thumb piezometric data control the transmissivity of the whole aquifer and any combination of hydraulic conductivities producing the same transmissivity could lead to a satisfactory fit of the data. So we chose to introduce a $2 \mathrm{~m}$ thick basal layer with hydraulic conductivity of $10^{-2} \mathrm{~m} / \mathrm{s}$ (coarse sand) which produces an adjusted permeability of $1.710^{-5} \mathrm{~m} / \mathrm{s}$ for the 48 upper meters of the aquifer, i.e. close to the hydraulic conductivity measured at the surface by Le Coz (2010). Our data are however not sensitive to the thickness and position of the high hydraulic conductivity layer, as long as it lies at depth in the aquifer and cannot act as a short circuit between the river and the piezometers. On the other hand, as the total transmissivity of the aquifer is unchanged, our hydraulic conductivity results cannot be reconciled with those obtained from models developed at the scale of the whole quaternary aquifer. The adjusted porosity is still 0.2 and the river coefficients are now $10,8.7,7.6$ and $12 \times 10^{-6} \mathrm{~ms}^{-1}$ for the years $2007-2008$ to 2010-2011, while the offset of $\mathrm{P} 1-3$ is $-0.54 \mathrm{~m}$. The river coefficients display a good regression $\left(R^{2}=0.96\right)$ when plotted against the mean height of the river during the flow season, which give some confidence on the physical consistency of the model and will allow estimating unknown C. It results that if the constant hydraulic conductivity model cannot be discarded from the water level data, the second model, relying on a high permeability basal layer is much more consistent with other informations on the aquifer. It will be therefore kept as the preferred solution.

\section{Comparison with previous data at the Assaga well}

A series of nearly monthly measurements lasting from 1994 to 1998 for both the water level in the Assaga well and the level of the KY at Bagara can be found in the Gaultier (2004) thesis and are displayed in Fig. OR2.3.

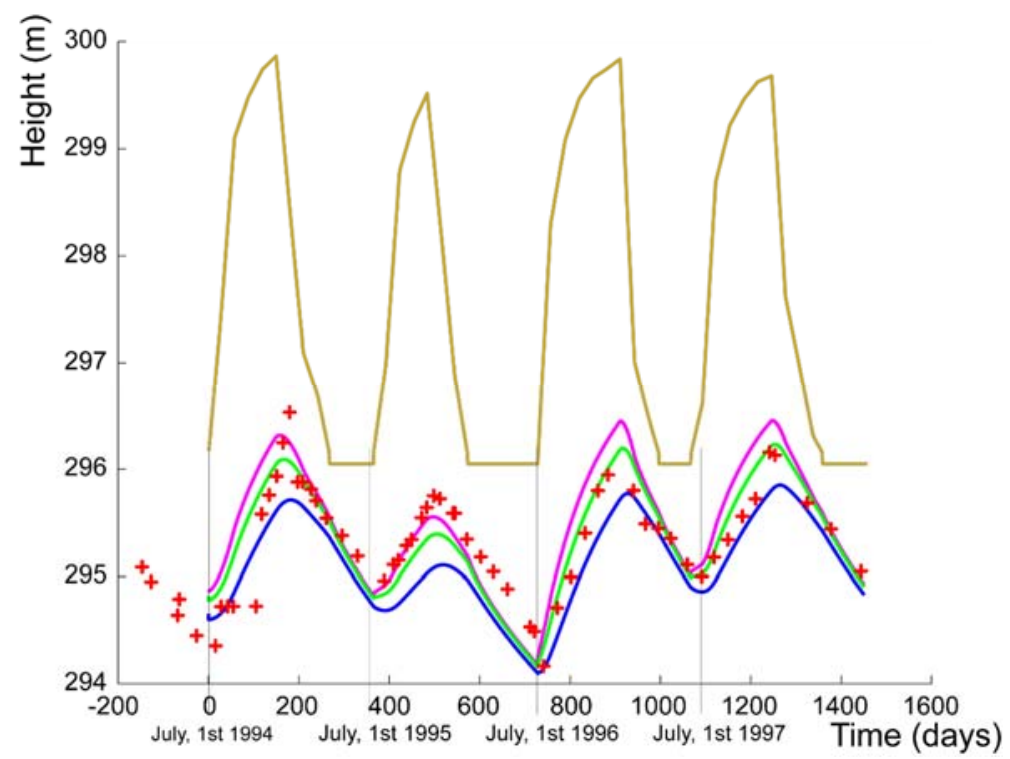

Fig. OR2.3 Comparison of observed water levels in the Assaga well (red crosses) with those simulated for the P1 (magenta), P2 (green) and P3 (blue) wells. The brown curve 
is the KY level. The Assaga well is located at a distance from the KY between those of $\mathrm{P} 1$ and $\mathrm{P} 2$.

The Assaga well is located within a meander of the $\mathrm{KY}$ at distances of $170 \mathrm{~m}$ and $430 \mathrm{~m}$ from the river on both sides of the meander, in an intensively cropped pepper area. This situation is therefore somewhat between those of $\mathrm{P} 1$ and $\mathrm{P} 2$. Keeping the basal high permeability layer and the irrigation recharge of $0.3 \mathrm{~m} / \mathrm{yr}$, the model has been forced with the 1994-1998 data of the KY levels, however keeping the geometry of the KY near P1-3. This approximation is justified by the proximity of Assaga well from the river, which makes it rather insensitive to the details of the shape of the river. The Assaga well has not been leveled, and it appears that its height, as given in the Gaultier's thesis (2004) is deduced from the topographic maps of the region, which can result in a several meters uncertainty and allows only relative height comparisons with the model. The 95-96 hydrologic year is a dry year and the three other years are average. The river coefficients have been estimated by interpolation of results of the previous section. Fig. OR2.3 shows that the water levels observed at Assaga are in fair agreement with those simulated for P1 and P2, in particular for the water drop after the 1995 dry year and its recovery during the 2 following years

It appears therefore, that in spite of the numerous approximations made in the model parameters, our model can provide some reasonable estimates of the groundwater level fluctuation outside its calibration period.

\section{Sensitivity to changes of $K$ and $C$}

\section{Decrease of permeability outside the KY valley.}

Exploration geophysics results suggest a lower hydraulic conductivity outside the KY valley. As the model is focused on the valley area, this will impact the boundary conditions of the model. As noted in section 4.1 of the main paper, yearly changes of the river axis do not propagate to the boundaries of the model. Therefore the modeling results are not sensitive to the boundary conditions; actually, they are mostly sensitive to the initial hydraulic head distribution, which are deduced from piezometric maps.

However, it should be noted that longer simulations, for example those dealing with the present climate change should take into account the permeability distribution outside the KY valley.

\section{Changes of $\mathrm{C}$ during the $\mathrm{KY}$ flow period.}

It is expected that the constant river-aquifer coefficient $C$ will stand for a lower coupling between the $\mathrm{KY}$ and the aquifer at the beginning of the flow period, when the aquifer is separated from the KY by a thick non saturated layer of low permeability and for a more efficient coupling at the end of the flow period. A variable $C$ would induce a slower rise of the water level in the aquifer at the beginning of the flow period, which will be mostly observed on the boreholes close to the river. However, we expect that the amplitude of water level changes in the aquifer will be controlled by the total infiltrated flux, and therefore by the mean value of $C$. A variable $C$ would therefore not impact strongly the water budget results, once the total amplitude of water level change is fitted to available data.

\section{References}

Descloitres M, Chalikakis K, Legchenko A, Moumouni A, Genthon P, Favreau G, Le Coz M, Boucher M, Oï M (2013) Groundwater resources estimation using MRS and electromagnetic surveys in the Komadugu Yobe valley, Lac Chad area, Niger. Afr J Earth Sci. doi: 10.1016/j.jafrearsci.2013.07.006

Le Coz M (2010) Modélisation hydrogéologique de dépôts hétérogénes: I'alluvium de la Komadougou Yobé, bassin du Lac Tchad, PhD Thesis, Univ. Montpellier II, France 
Gaultier G (2004) Recharge et paléo-recharge d'une nappe aquifère libre en milieu sahélien (Niger Oriental). Approches géochimiques et hydrodynamiques, PhD Thesis, Univ. PXI, Paris 